\title{
Secondary Involvement of the Penis by Non-Hodgkin Lymphoma
}

\author{
Non-Hodgkin Lenfomanın İnfiltrasyonuna Sekonder Penis Tutulumu
}

\section{(1) Gizem TIMOÇIN YIĞMAN, ib Abdusselim Adil PEKER, id Rasul SHARIFOV, iD Hüseyin TOPRAK}

Bezmialem Vakıf University Faculty of Medicine, Department of Radyology, İstanbul, Turkey

\begin{abstract}
Primary penile lymphoma is extremely rare and there are less than 30 reported cases worldwide. Frequently penile lymphoma is seen as a secondary involvement of the penis by lymphoma, most likely by Non-Hodgkin lymphoma (NHL). Here, we report a case with penile lymphoma caused by previously known NHL.
\end{abstract}

Keywords: Non-Hodgkin lymphoma, penis, MRI, penile lymphoma

\section{ÖZ}

Penil lenfoma oldukça nadirdir. Toplamda 30 olgunun olduğu bildirilmiştir. Penil lenfoma tutulumu genellikle lenfomanın sekonder tutulumu şeklinde karşımıza çıkmaktadır. Genellikle Non-Hodgkin lenfomanın (NHL) sekonder tutulumu şeklindedir. Bilinen NHL tanılı olguda penisin sekonder tutulumunun olduğu olguyu sunacağı.

Anahtar Sözcükler: Non-Hodgkin lenfoma, penis, MRG, penil lenfoma

\section{Introduction}

Penile malignant tumours are uncommon. The ultrasonography discloses that penile cancer accounts for around $0.4 \%$ of all male malignancies. Primary penile lymphoma is extremely rare (less than 30 cases) (1). The penile lymphoma is often seen as the secondary involvement of the penis, most likely by Non-Hodgkin lymphoma (NHL) (2-4). In most cases, penile lymphoma represents secondary involvement due to haematogenous or lymphatic spread or direct extension from a neighbouring organ (5), such as bladder, lymph nodes and seminal vesicles. For the diagnosis, physical examination and radiological imaging [computed tomography (CT) and magnetic resonance imaging (MRI)] should be carefully undertaken (5). In this case, we report a case with penile lymphoma caused by previously known NHL.

\section{Case Report}

A 58-year-old male presented with penis pain and erectile dysfunction; he had a history of NHL for 4 years, and he was getting chemotherapy. His physical examination indicated a dysmorphic penile shaft, and the prostate was hard. The clinician suspected Peyronie's disease. Routine blood, liver and renal function tests were normal. His urine leukocyte level was high [12 high pass filter (HPF); normal 0-5 HPF]. Multiple enlarged inguinal lymph nodes and minimal abdominal tenderness were noted. Abdominal ultrasound showed hepatomegaly, hepatosteatosis and normal configuration of both kidneys. MRI of the pelvis and penis showed isointense on $\mathrm{T} 1$ weighted imaging and hypointense on T2 weighted imaging signal changes and homogenous contrast enhancement on post-contrast T1 images

Address for Correspondence: Gizem TiMOÇiN YIČMAN, Bezmialem Vakıf University Faculty of Medicine, 
in the corpus spongiosum of the penis (Figure 1, 5). Diffusionweighted imaging shows restricted diffusion (Figure 2). Also, the central and peripheral zone of the prostate and left seminal vesicle were involved (Figure 3,4). Bilateral obturator, external and inguinal lymph nodes were enlarged. With these findings, the diagnosis of penile lymphoma due to the involvement of the penis by NHL was established. And his treatment (systemic chemotherapy), which he had already taken, was continued. After chemotherapy, clinical response was observed. The symptoms of the patients were all reduced.

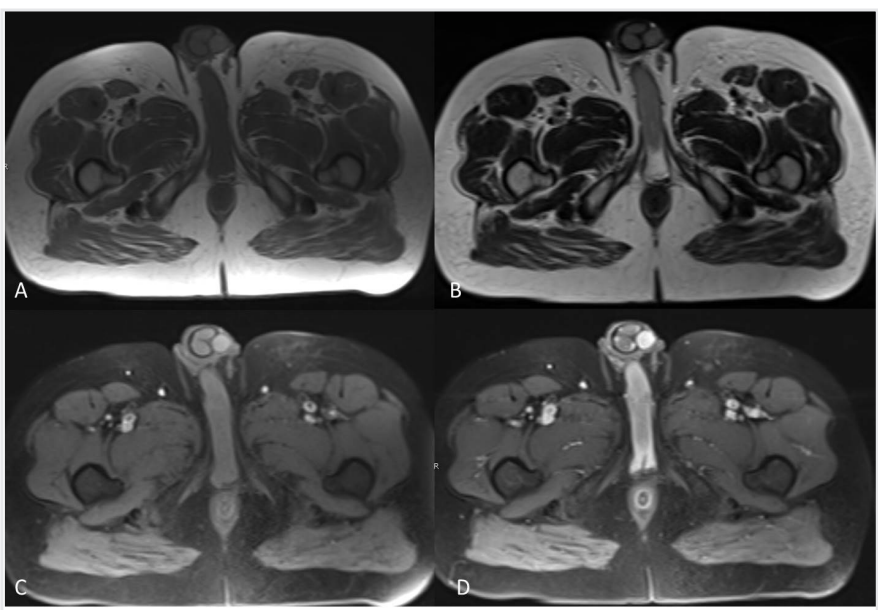

Figure 1. (A) Axial T1 weighted image showed homogeneous isointensity in the corpus spongiosum penis and (B) axial T2 weighted image showed hypointensity of the corpus spongiosum. (C) axial fat sat T1 weighted image and (D) axial fat sat T1 postcontrast image showed homogenous contrast enhancement in the corpus spongiosum of penis

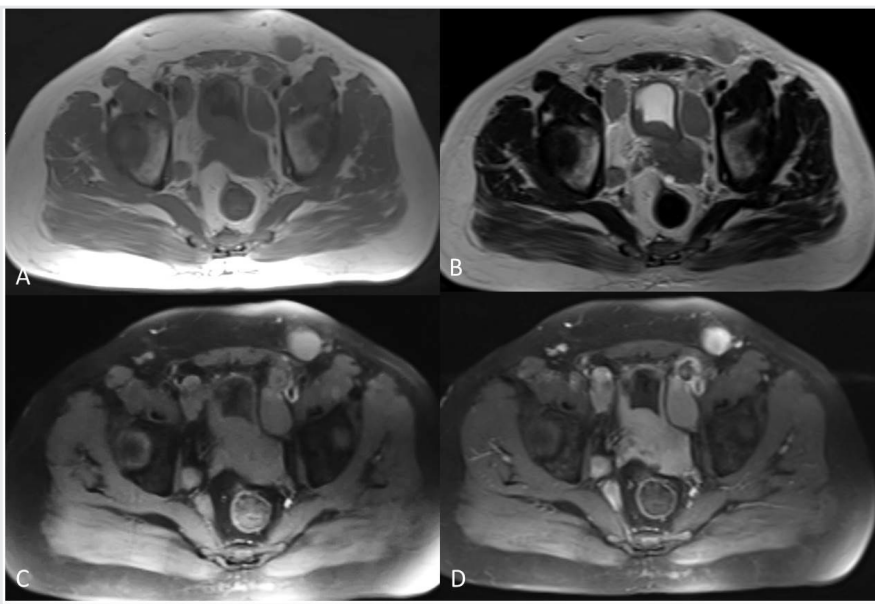

Figure 2. (A) Axial T1 weighted image and (B) axial T2 weighted image showed enlarged bilateral obturator and inguinal lymph nodes. (C) Axial fat sat T1 weighted image and (D) axial fat sat T1 postcontrast image showed homogenous contrast enhancement on this lymph nodes

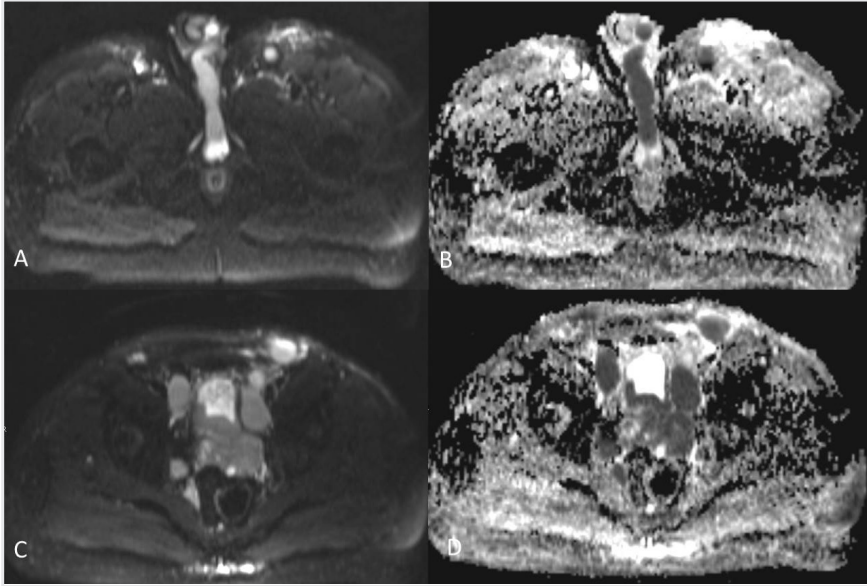

Figure 3. Axial Diffusion weighted images (A-B) in the corpus spongiosum and (C-D) prostate and left seminal vesicle shows diffusion restriction

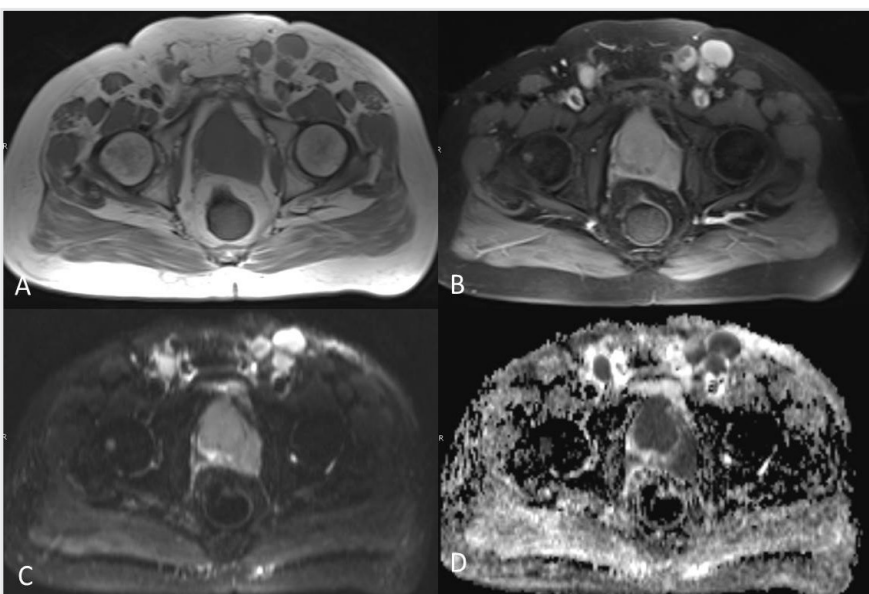

Figure 4. (A) Axial T1 weighted image showed enlarged inguinal lymph nodes and (B) axial fat sat T1 postcontrast image showed homogenous contrast enhancement in this lymph nodes. Axial Diffusion weighted images (C-D) left inguinal lymph nodes, prostate and left seminal vesicle shows diffusion restriction

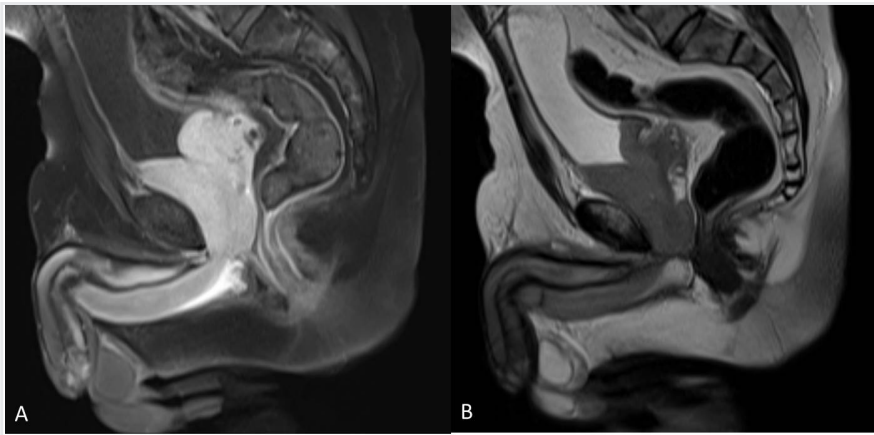

Figure 5. (A) Saggital T1 weighted image showed homogeneous isointensity in the corpus spongiosum of penis and (B) Saggital fat sat T1 postcontrast image showed homogenous contrast enhancement in the corpus spongiosum of penis 


\section{Discussion}

NHL is generally observed in large, conglomerated lymph nodes. However, it can also occur outside the lymph nodes, called extra-nodal lymphoma. Extra-nodal lymphoma can also be seen in the gastrointestinal tract, liver, spleen, Waldeyer's lymphatic ring, skin, central nervous system, bone, thyroid gland and the urogenital system, although with low probability (7). Primary penile lymphoma is extremely rare, with less than 30 cases reported in the literature. Secondary involvement of the penis can occur due to retrograde spread or to direct extension from the neighbouring organ (5). The affected locations are the penile shaft (most common) and glans penis (4,6). Lymphoma of the penis can present as a nodule, painless mass, plaques or ulcers and results in a dysmorphic appearance of the penile shaft. Painless mass is the most common symptom, followed by the ulcer (1). When the corpus cavernosum of the penis is involved, erectile dysfunction and penile swelling can be seen. Radiological modalities such as CT, MRI and PET CT should be undertaken for treatment and prognosis. MRI of most penile cancers shows superficial, hypointense infiltrative soft-tissue masses on T1- and T2-weighted imaging (2). After intravenous contrast injection, lesions enhance homogeneously. In the present case, after an early consideration of the diagnosis of Peyronie's disease, the final diagnosis of NHL of the penis was confirmed by MRI images (6).

Systemic chemotherapy is the treatment of choice for the second presentation of lymphoma in the penis. Chemotherapy has the clear advantage of obtaining good cosmetic and functional results (1). Radical surgery can also be used, but only after the failure of other modalities like local radiotherapy, immunotherapy and combined modalities (3).

In conclusion, the penile malignant tumour and penile lymphoma are very rare and can be mistaken for other soft-tissue tumours, and hence it poses a significant differential diagnostic challenge (2). If the patient diagnosed with squamous cell carcinoma of the penis, treatment typically consists of radical penectomy $(3,8)$. Excision biopsy is essential to reach the final diagnosis (7). Other differential diagnosis includes vasculitis, trauma nad sexually transmitted disease (1).

MRI plays a vital role in diagnosing penile lymphoma and assessing the local extent of the disease.

\section{Ethics}

\section{Informed Consent:}

Peer-review: Externally peer reviewed.

\section{Authorship Contributions}

Concept: G.T.Y., A.A.P., R.S., H.T., Design: G.T.Y., A.A.P., R.S., H.T., Data Collection or Processing: G.T.Y., A.A.P., R.S., H.T., Analysis or Interpretation: G.T.Y., A.A.P., R.S., H.T., Literature Search: G.T.Y., A.A.P., R.S., H.T., Writing: G.T.Y., A.A.P., R.S., H.T.

Conflict of Interest: No conflict of interest was declared by the authors.

Financial Disclosure: The authors declared that this study received no financial support.

\section{References}

1. Stamatiou K, Pierris N. Lymphoma presenting as cancer of the glans penis: a case report. Case Rep Pathol 2012;2012:948352.

2. Thomas K, Spiess P, Caracciolo JT. A report of two deep-seated noncutaneous penile tumors: more than meets the eye. Radiol Case Rep 2017;12:726-30.

3. Gentile G, Broccoli A, Brunocilla E, Schiavina R, Borghesi M, Romagnoli $\mathrm{D}$, et al. An isolated penile mass in a young adult turned out to be a primary marginal zone lymphoma of the penis. A case report and review of literature. Anticancer Res 2013;33:2639-42.

4. Singh AK, Saokar A, Hahn PF, Harisinghani MG. Imaging of penile neoplasms. Radiographics 2005;25:1629-38.

5. Chiang KH, Chang PY, Lee SK, Yen PS, Ling CM, Lin CC, et al. MR findings of penile lymphoma. Br J Radiol 2006;79:526-8.

6. Karki K, Mohsin R, Mubarak M, Hashmi A. Primary Non-Hodgkin's Lymphoma of Penis Masquerading as a Non-Healing Ulcer in the Penile Shaft. Nephrourol Mon 2013;5:840-2.

7. Wang GC, Peng B, Zheng JH. Primary penile malignant lymphoma: report of a rare case. Can Urol Assoc J 2012;6:277-9.

8. Marchionne E, Perez C, Hui A, Khachemoune A. Penile squamous cell carcinoma: a review of the literature and case report treated with Mohs micrographic surgery. An Bras Dermatol 2017;92:95-9. 